\title{
Penampilan Produksi Kelinci Fase Pertumbuhan Menggunakan Wafer Ransum Komplit Berbahan Tepung Inti Biji Karet
}

\author{
Ade Saptika Rasmi, Anwar Efendi Harahap* dan Hidayati \\ Program Studi Peternakan Fakultas Pertanian dan Peternakan, UIN Sultan Syarif Kasim Riau \\ Jl. H.R. Soebrantas No. 155 KM 15 Tuahmadani Tampan Pekanbaru 28293 \\ Email*: neniannisaharahap@yahoo.co.id
}

\begin{abstract}
Abstrak
Biji karet adalah limbah hasil pertanian yang dapat dimanfaatkan sebagai pakan alternatif. Penggunaan biji karet saja tidak cukup untuk memenuhi kebutuhan kelinci, diperlukan pakan tambahan untuk melengkapinya untuk mencampur bahan tersebut diperlukan teknologi, teknologi yang dapat digunakan salahsatunya wafer. Penelitian ini bertujuan untuk mengetahui penampilan produksi kelinci fase pertumbuhan dengan menggunakan wafer ransum komplit dengan penambahan $0 \%, 3 \%, 6 \%$ dan $9 \%$ tepung inti biji karet. Pengamatan yang dilakukan pada penelitian ini adalah pertambahan bobot badan, konsumsi pakan, konversi pakan dan biaya pakan. Penelitian ini menggunakan Rancangan Acak Lengkap (RAL) yang terdiri dari 4 perlakuan dan 3 ulangan. Penambahan tepung biji karet dalam ransum komplit hingga taraf $9 \%$ belum dapat memperbaiki performa produksi kelinci lokal jantan fase pertumbuhan yang dilihat dari konsumsi pakan, pertambahan bobot badan dan konversi pakan. Biaya pakan yang tinggi terdapat pada perlakuan dengan penambahan 3\% tepung inti biji karet dan biaya pakan yang terendah terdapat pada perlakuan dengan penamabahan $9 \%$ tepung inti biji karet

Katakunci: kelinci, biji karet, wafer dan performa
\end{abstract}

\begin{abstract}
Rubber seed is agricultural waste can used for alternatif feed. Rubber seed use not enough for make ends meet rabbit, additional feed is needed to complete it to mix the ingredient needed technology, technology that can be used, one of which is wafers. This study aims to determine the performance of the growth phase of rabbit production by using a complete wafer ration with the addition of $0 \%, 3 \%, 6 \%$ and $9 \%$ rubber seed core flour. Observations made in this study were body weight gain, ration consumtion, ration conversion, and feed costs. This study using completely randomized design (CRD), which consists of 4 treatments and 3 replications. Addition of rubber seed flour in ingredients not significantly up to the level of $9 \%$ the production performance of male local rabbits in the growth phase seen from ration consumtion, body weight gain, ration consumtion, and ration conversion. High feed cost is found in the addition of 3\% of rubber seed core flour and the lowest feed cost is found in the addition of $9 \%$ of rubber seed core flour.

Keywords: rabbit, rubber seed, wafer, performance.
\end{abstract}

\section{Pendahuluan}

Kelinci merupakan salah satu ternak alternatif penghasil daging sebagai sumber protein dan kelinci juga mempunyai laju pertumbuhan dan perkembangbiakan yang relatif cepat. Kelinci termasuk ke dalam ternak monogastrik. Ternak kelinci menjadi pilihan untuk dibudidayakan secara luas, karena harganya yang terjangkau. Kemampuan kelinci menggunakan berbagai jenis pakan, memudahkan kelinci untuk dipelihara di berbagai tempat dengan memanfaatkan potensi sumber daya pakan lokal. Menurut Sitorus dkk., (1982), di negara berkembang, kelinci dapat dipelihara menggunakan hijauan yang dikombinasikan dengan limbah pertanian dan limbah hasil industri pertanian. Limbah 


\section{Jurnal Sains Peternakan}

Volume 8 No. 1, Juni 2020, pp:1-11

ISSN 2579-4450

pertanian yang dapat dimanfaatkan sebagai pakan alternatif kelinci salah satunya adalah biji karet.

Berdasarkan data dari Dinas Perkebunan Provinsi Riau (2015), luas lahan perkebunan karet di Riau mencapai 501.788 ha dengan produksi perkebunan mencapai 74.285 ton/ha. Perkebunan karet di Kabupaten Kampar berada pada urutan kedua terluas dari dua belas kabupaten di Provinsi Riau, total luas adalah 102.234 ha. Rahmawan $d k k$, (2008) menyatakan $80 \%$ tanaman karet menghasilkan buah karet dengan produksi satu ton per hektar per tahun, maka dari luas areal tanaman karet 102.234 hektar dihasilan 81.787 ton biji karet per tahun. Oleh karena itu biji karet yang merupakan limbah hasil pertanian dapat dimanfaatkan sebagai pakan alternatif.

Biji karet mempunyai komposisi zat nutrisi yang relatif cukup baik yaitu protein kasar 17,7\% dan serat kasar 5,2\% (Endrayani, 2006). Dilihat dari aspek gizinya, biji karet memiliki protein yang relatif cukup baik yaitu 17,54 \% (Anggraeni dan Afzalani, 1990), dan nilai hampir sama dengan nilai protein kasar limbah perkebunan lainnya, seperti bungkil kelapa, yakni 19,20 \% (NRC, 1994). Namun, di sisi lain biji karet juga mengandung zat anti nutrisi berupa asam sianida $(\mathrm{HCN})$ yang cukup tinggi yaitu sebesar $330 \mathrm{mg} / 100 \mathrm{~g}$ bahan (Siahaan, 2009). HCN pada biji karet dapat dihilangkan dengan cara perendaman dan perebusan (Karima, 2015).

Penggunaan inti biji karet yang dijadikan tepung saja tidak cukup untuk memenuhi kebutuhan ternak, dibutuhkan pakan tambahan untuk menyusun keseimbangan ransum menjadi pakan komplit untuk memenuhi kebutuhan pakan ternak. Pakan tambahan yang dipilih untuk memenuhi kebutuhan ternak selain juga dilihat dari kandungan nutrisinya juga diperhatikan rancangan anggaran biaya yang dikeluarkan antara lain tepung jagung selain kandungan nutrisinya dan bahan yang mudah didapat, harga yang ditawarkan juga terjangkau. Dedak padi yang diperoleh dari pabrik lebih menguntungan. Bungkil kedelai relatif memiliki harga yang lebih tinggi dibandingkan yang lainnya.

Semua bahan tersebut harus dicampur untuk membuat ransum komplit. Salah satu teknologi yang dapat diterapkan dalam upaya meningkatkan kualitas mutu pakan, memudahkan penyimpanan serta dapat disimpan dalam waktu relatif lama yaitu memanfaatkan teknologi dengan membuat wafer. Menurut Utari dkk., (2012), wafer ransum komplit merupakan suatu bentuk pakan yang memiliki bentuk fisik kompak dan ringkas sehingga diharapkan dapat memudahkan dalam penanganan dan transportasi, disamping itu memiliki kandungan nutrisi yang lengkap, dan menggunakan teknologi yang relatif sederhana sehingga mudah diterapkan, salah satunya adalah wafer. Patrick 


\section{Jurnal Sains Peternakan}

Volume 8 No. 1, Juni 2020, pp:1-11

ISSN $2579-4450$

and Schaible, (1980) menjelaskan keuntungan pakan berbentuk wafer adalah meningkatkan konsumsi dan efisiensi pakan, meningkatkan kadar energi metabolis pakan, membunuh bakteri patogen, menurunkan jumlah pakan yang tercecer, memperpanjang lama penyimpanan, menjamin keseimbangan zat-zat nutrisi pakan dan mencegah oksidasi vitamin.

Wafer ransum komplit merupakan suatu bentuk pakan yang memiliki bentuk fisik kompak dan ringkas sehingga diharapkan dapat memudahkan dalam penanganan dan transportasi, disamping itu memiliki kandungan nutrisi yang lengkap, dan menggunakan teknologi yang relatif sederhana sehingga mudah diterapkan (Trisyulianti $d k k$., 2003). Wafer sendiri banyak diberikan kepada ternak ruminansia, sedangkan untuk pakan kelinci lebih sering diberikan dalam bentuk hay, konsentrat, pellet maupun yang diberikan secara langsung (bahan mentah tanpa pengolahan).

\section{Materi dan Metode}

\section{Materi Penelitian}

Bahan yang digunakan dalam penelitian ini adalah kelinci lokal jantan sebanyak 12 ekor berumur \pm empat bulan dengan bobot badan rata-rata 1.100 gram. Bahan pakan penyusun ransum terdiri dari rumput lapang, dedak jagung, dedak padi halus, bungkil kedelai, tepung inti biji karet, air dan molases.

Alat yang digunakan adalah 12 petak kandang dengan ukuran $(75 \times 40 \times 45) \mathrm{cm}$, dengan alas kandang terbuat dari bambu. Peralatan kandang terdiri dari tempat pakan dan tempat minum. Untuk pembuatan wafer terdiri dari timbangan, mesin grinding, mesin wafer, baskom, gelas ukur, kantong plastik, nampan, terpal, alat tulis, dan kamera.

\section{Metode Penelitian}

Penelitian dilakukan secara eksperimen dengan menggunakan Rancangan Acak Lengkap (RAL) yang terdiri dari 4 perlakuan dengan 3 ulangan, sedangkan pengamatan biaya pakan dilakukan dengan analisis deskriptif. Setiap ulangan terdiri dari 1 ekor kelinci tiap satu petak kandang. Kelinci-kelinci tersebut secara acak diberi 4 perlakuan pakan yang berbeda. Perlakuan yang digunakan adalah:

A0 : Wafer tanpa Penambahan Tepung Inti Biji Karet (kontrol)

A1 : Wafer dengan Penambahan 3\% Tepung Inti Biji Karet

A2 : Wafer dengan Penambahan 6\% Tepung Inti Biji Karet

A3 : Wafer dengan Penambahan 9\% Tepung Inti Biji Karet

Nilai nutrisi bahan pakan penyusun ransum disajikan pada Tabel 1 dan susunan ransum perlakuan untuk kelinci ditampilkan pada Tabel 2 . 
Tabel 1. Nilai Nutrisi Bahan Pakan Penyusun Ransum

\begin{tabular}{lllllllc}
\hline No & Bahan Pakan & PK\% & $\begin{array}{l}\text { Energi } \\
\mathrm{kkal} / \mathrm{kg}\end{array}$ & Lemak\% & $\mathrm{SK} \%$ & $\mathrm{Ca} \%$ & $\mathrm{P} \%$ \\
\hline 1 & Rumput Lapang* & 6,96 & $3.376,00$ & 1,84 & 32,55 & 0,40 & 0,20 \\
2 & Dedak Jagung** & 9,72 & $3.975,18$ & 2,90 & 4,00 & 0,49 & 0,19 \\
3 & Dedak Padi & 8,58 & $1.630,00$ & 10,75 & 21,57 & 0,14 & 0,60 \\
& Halus** & & & & & \\
4 & Bungkil Kedele** & 40,05 & $2.240,00$ & 4,08 & 5,29 & 0,47 & 0,19 \\
5 & Tepung Biji & 3,85 & $6.179,00$ & 49,39 & 15,23 & - & - \\
& Karet**** & & & & & & \\
\hline
\end{tabular}

Sumber : $\quad$ Analisis Laboratorium Fakultas Pertanian UR (2018)*

$$
\begin{aligned}
& \text { Diansyah }(2016)^{* *} \\
& \text { Ma'rufah }(2016)^{* * *} \\
& \text { Lubis (2017)**** }
\end{aligned}
$$

\begin{tabular}{|c|c|c|c|c|}
\hline Bahan pakan & A0 & A1 & A2 & A3 \\
\hline Rumput lapang & 19,00 & 19,00 & 19,00 & 19,00 \\
\hline Dedak jagung & 30,00 & 27,00 & 24,00 & 24,00 \\
\hline Dedak padi halus & 23,00 & 23,00 & 23,00 & 20,00 \\
\hline Bungkil kedelai & 28,00 & 28,00 & 28,00 & 28,00 \\
\hline Tepung Biji Karet & 0,00 & 3,00 & 6,00 & 9,00 \\
\hline Molases & 5,00 & 5,00 & 5,00 & 5,00 \\
\hline \multicolumn{5}{|c|}{ Kandungan Nutrisi (\%) } \\
\hline Protein kasar & 17,43 & 17,25 & 17,07 & 16,76 \\
\hline Energi kkal/kg & $2.836,09$ & $2.902,21$ & $2.968,32$ & $2.918,75$ \\
\hline Lemak & 4,83 & 6,23 & 7,62 & 8,69 \\
\hline Serat kasar & 13,83 & 14,16 & 14,50 & 12,46 \\
\hline Kalsium & 0,39 & 0,37 & 0,36 & 0,25 \\
\hline Phospor & 0,29 & 0,28 & 0,27 & 0,29 \\
\hline
\end{tabular}

Adapun susunan ransum perlakuan untuk kelinci dapat dilihat pada Tabel 2

Tabel 2. Susunan Ransum Perlakuan untuk Kelinci

\section{Prosedur Penelitian}

Adapun prosedur penelitian dapat dilihat pada Gambar dibawah ini

\section{Pembuatan Tepung Biji Karet}

Tepung biji karet dibuat melalui proses pengolahan biji karet menurut Parrakkasi (1995) yang telah dimodifikasi seperti diagram alir pada Gambar 1 


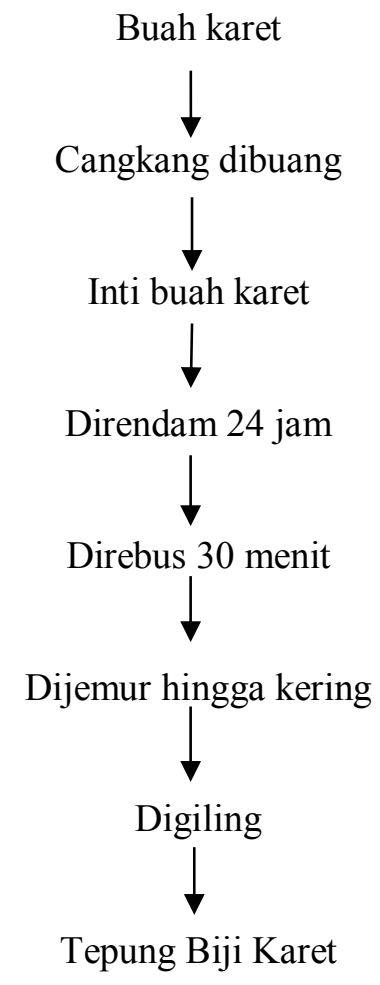

Gambar 1. Diagram Alir Proses Pengolahan Biji Karet

\section{Pembuatan Wafer Tepung Biji Karet}

Pembuatan wafer dapat dilihat dari Gambar 2

Masing-masing bahan ditimbang sesuai dengan kebutuhan<smiles>[3H][13CH3]</smiles>

Pencampuran bahan hingga menjadi homogen

Masukkan bahan ke dalam gelas kimia sebanyak $100 \mathrm{ml}$

Tuangkan bahan tersebut kedalam cetakan $(5 \times 5 \times 5 \mathrm{~cm})$ yang ada pada mesin wafer<smiles>C1C[Te][Te]1</smiles>

Dilakukan proses pengepresan selama 15 menit

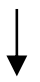

Dinginkan di ruang terbuka

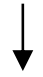

Jemur dibawah sinar matahari (4-5 jam)

Simpan dalam kantong plastik kaca yang diberi rongga

Gambar 2. Diagram Alir Proses Pembuatan Wafer 


\section{Jurnal Sains Peternakan}

Volume 8 No. 1, Juni 2020, pp:1-11

ISSN 2579-4450

\section{Aplikasi Ransum Wafer Terhadap Kelinci}

Penelitian ini dilaksanakan selama 6 minggu. Sebelum diberikan perlakuan, dilakukan masa adaptasi selama 1 minggu. Pada masa adaptasi kelinci diberikan satu keping wafer dan hijauan. Minggu kedua dan minggu kelima (pengambilan data) kelinci diberikan wafer dua keping pada pagi hari dan tiga keping pada sore hari.

\section{Peubah yang Diamati}

Peubah yang diamati pada penelitian ini adalah pertambahan bobot badan, konversi pakan dan konsumsi pakan (g/ekor).

\section{Konsumsi Pakan}

Konsumsi pakan dihitung dengan cara menimbang jumlah pakan yang diberikan, dikurangi dengan sisa pakan selam pemeliharaan ( Wiqar, 2009).

Konsumsi Pakan $(\mathrm{g} /$ ekor selama penelitian $)=$ Pakan yang diberikan - Sisa pakan

\section{Pertambahan Bobot Badan}

Pertambahan bobot badan merupakan selisih antara bobot badan awal dengan bobot badan akhir dibagi dengan lama pemeliharaan dinyatakan dalam gram/ekor (Wiqar, 2009).

Pertambahan bobot badan $=\frac{\text { Bobot Badan Akhir }(\mathrm{g})-\text { Bobot Badan Awal }(\mathrm{g})}{\text { Waktu pemeliharaan }(\text { hari })}$

\section{Konversi Pakan}

Konversi pakan dihitung dengan membagi jumlah pakan yang dikonsumsi (gram/ ekor selama penelitian) dengan pertambahan bobot badan (gram/ ekor selama penelitian).

$$
\text { Konversi Pakan }=\frac{\text { Konsumsi Pakan }\left(\frac{\mathrm{g}}{\text { ekor }} \text { selama penelitian }\right)}{\text { Pertambahan Bobot Badan }\left(\frac{\mathrm{g}}{\text { ekor }} \text { selama penelitian }\right)}
$$

\section{Biaya Pakan}

Biaya pakan dihitung dengan cara:

Harga pakan per $\mathrm{kg}=\%$ dalam formulasi ransum $\times$ harga pakan per $\mathrm{kg}$ bahan pakan

Harga pakan per ekor kelinci selama penelitian $=$ Konsumsi pakan $\times$ harga pakan per $\mathrm{kg}$

\section{Analisis Data}

Data yang diperoleh diolah menurut analisis Sidik Ragam Rancangan Acak Lengkap (RAL) menurut Steel dan Torrie (1991) model linier Rancangan Acak Lengkap adalah sebagai berikut:

$$
Y i j=\mu+\alpha i+€ i j
$$




\section{Jurnal Sains Peternakan}

Volume 8 No. 1, Juni 2020, pp:1-11

ISSN 2579-4450

\section{Hasil dan Pembahasan}

\section{Konsumsi Ransum}

Konsumsi adalah faktor esensial yang merupakan dasar untuk hidup dan menentukan produksi (Pratiwi, 2008). Rataan konsumsi ransum kelinci untuk masingmasing perlakuan disajikan pada Tabel 3.

Tabel 3. Rata-rata konsumsi ransum kelinci berbahan tepung inti biji karet selama penelitian (g/ekor)

\begin{tabular}{lr}
\hline Penambahan tepung biji karet (\%) & Rataan dan Stdev (gram) \\
\hline Tanpa biji karet & $4.306,00 \pm 857,52$ \\
3 & $4.711,67 \pm 62,93$ \\
6 & $4.364,33 \pm 113,07$ \\
9 & $4.137,00 \pm 197,44$ \\
\hline
\end{tabular}

Keterangan: Data yang ditampilkan adalah rataan \pm stdev

Tabel 3 menunjukkan rataan masing-masing konsumsi pakan perlakuan tanpa biji karet, 3\%, 6\% dan 9\% berturut-turut adalah 4.306,00, 4.711,67, 4.364,33 dan 4.137,00 (g/ekor). Berdasarkan hasil analisis sidik ragam penambahan tepung inti biji karet tidak berpengaruh nyata $(\mathrm{P}>0,05)$ terhadap konsumsi pakan kelinci fase pertumbuhan selama penelitian. Hal ini kemungkinan disebabkan karena tingkat palatabilitas pakan yang diberikan tepung inti biji karet hingga level $9 \%$ relatif sama. Kondisi ini didukung dengan kandungan protein kasar dan energi metabolis ransum penelitian relatif sama yaitu $16-17 \%$ dan $2.836,09-2.968,32 \mathrm{kkal} / \mathrm{kg}$. Hal ini sesuai dengan yang disampaikan oleh Parakkasi (1999) bahwa tinggi rendahnya konsumsi pakan dipengaruhi oleh palatabilitas.

Selanjutnya kemungkinan konsumsi pakan yang tidak berbeda juga karena kandungan energi dalam ransum dimana tingkat energi dalam ransum menentukan banyaknya pakan yang dikonsumsi, bila masing-masing perlakuan mempunyai ransum dengan energi yang relatif sama menyebabkan tidak adanya perbedaan konsumsi ransum. Hal ini sesuai dengan pernyataan Wiqar (2009), yang menyatakan energi yang relatif sama pada ransum menyebabkan kelinci mengkonsumsi ransum dalam jumlah yang relatif sama pula.

Hasil penelitian ini lebih tinggi dibandingkan dengan penelitian yang dilakukan oleh Pratiwi (2008) tentang substitusi konsentrat dengan tepung biji karet dalam ransum sampai taraf $15 \%$ dimana nilai rataan konsumsi pakan berkisar 76,82- 80,93 gr/ekor/hari. Penelitian lain yang dilakukan oleh Tarmanto (2009) tentang performan produksi kelinci New zealand white jantan dengan bagasse fermentasi dengan nilai rerata yang hampir sama dengan penelitian ini dimana rataannya 120,44 - 143,57 gr/ekor/hari. 


\section{Jurnal Sains Peternakan}

Volume 8 No. 1, Juni 2020, pp:1-11

ISSN 2579-4450

\section{Pertambahan Bobot Badan}

Pertambahan bobot badan dapat digunakan sebagai peubah untuk mengetahui pertumbuhan kelinci. Pertambahan bobot badan merupakan selisih dari bobot badan (panen) dengan bobot badan awal pada saat tertentu (Fahrudin, dkk., 2016). Rataan pertambahan bobot badan kelinci untuk masing-masing perlakuan disajikan dalam Tabel 4

Tabel 4. Rata-rata pertambahan bobot badan kelinci selama lima minggu (gr/ekor)

\begin{tabular}{lr}
\hline Penambahan tepung biji karet (\%) & Rataan dan Stdev (gram) \\
\hline Tanpa biji karet & $1.433,33 \pm 680,39$ \\
3 & $1.546,67 \pm 166,53$ \\
6 & $1.633,33 \pm 136,14$ \\
9 & $1.426,67 \pm 75,72$ \\
\hline
\end{tabular}

Keterangan: Data yang ditampilkan adalah rataan \pm stdev

Tabel 4 menunjukkan rataan pertambahan bobot badan kelinci berturut-turut $1.433,33,1.546,67,1.633,33$ dan 1.426,67 (gr/ekor). Berdasarkan hasil analisis sidik ragam menunjukkan bahwa penambahan tepung biji karet sampai level 9\% tidak berpengaruh nyata $(\mathrm{P}>0,05)$ terhadap pertambahan bobot badan kelinci. Hal ini diduga karena konsumsi pakan yang dihasilkan juga tidak berbeda nyata. Selain itu energi yang relatif sama dan lemak yang tinggi menyebabkan kelinci mengkonsumsi pakan yang sedikit sehingga pertambahan bobot badan tidak berbeda nyata. Nilai rataan perhari Pertambahan bobot badan pada penelitian ini lebih rendah yaitu 40,76- 46,64 gr dibandingkan dengan hasil penelitian Pratiwi (2008), substitusi konsentrat dengan tepung biji karet dalam ransum sampai taraf $15 \%$ dimana nilai rerata 51,52 - 65,66 gr/ekor/ hari. Penelitian lain yang dilakukan oleh Wiqar (2009), tentang pengaruh substitusi konsentrat dengan tepung daun wortel dalam ransum terhadap performan kelinci lokal jantan dimana nilai rataan yang lebih rendah dari penelitian ini yaitu $65,66-74,48 \mathrm{gr} / \mathrm{ekor} / \mathrm{hari}$.

\section{Konversi Pakan}

Rataan konversi pakan tiap perlakuan disajikan dalam Tabel 5.

Tabel 5. Rata-rata konversi pakan kelinci selama penelitian

\begin{tabular}{lr}
\hline Penambahan tepung biji karet (\%) & Rataan dan Stdev \\
\hline Tanpa biji karet & $3,44 \pm 1,39$ \\
3 & $3,07 \pm 0,34$ \\
6 & $2,68 \pm 0,17$ \\
9 & $2,90 \pm 0,06$ \\
\hline
\end{tabular}

Keterangan: Data yang ditampilkan adalah rataan \pm stdev

Tabel 5. menunjukkan rataan masing-masing konversi pakan kelinci perlakuan tanpa biji karet, 3\%, 6\% dan 9\% berturut-turut adalah 3,44, 3,07, 2,68 dan 2,90. 


\section{Jurnal Sains Peternakan}

Volume 8 No. 1, Juni 2020, pp:1-11

ISSN 2579-4450

Berdasarkan hasil analisis sidik ragam penambahan tepung inti biji karet dalam ransum komplit hingga taraf $9 \%$ tidak berbeda nyata $(\mathrm{P}>0,05)$ terhadap konversi pakan kelinci. Hal ini dipengaruhi oleh konsumsi pakan dan pertambahan bobot badan dalam penelitian ini juga menunjukkan nilai yang tidak berbeda nyata $(\mathrm{P}>0,05)$. Menurut Kamal (1997), konversi pakan merupakan nilai dari hasil pembagian antara nilai konsumsi dan pertambahan bobot badan dalam satuan bobot dan waktu yang sama. Efisiensi pakan dapat dilihat dari nilai konversi pakan, semakin rendah nilai konversi pakan maka efisiensi penggunaan pakan semakin tinggi (Maryani $d k k$., 2015). Wiqar (2009), menambahkan semakin kecil konversi pakan menunjukkan semakin sedikitnya pakan yang dibutuhkan untuk menghasilkan bobot badan dalam satuan yang sama.

Konversi pakan pada penelitian ini lebih rendah $(2,92-3,26)$ dibandingkan dengan hasil penelitian yang dilakukan Pratiwi (2008), substitusi konsentrat dengan tepung biji karet dimana nilai rataan konversi pakan adalah 8,33-12,00. Hasil konversi penelitian lain juga lebih rendah dibandingkan dengan Wiqar (2009) yang menggunakan pakan bagasse fermentasi pada kelinci New Zealand White dengan nilai rataan 7,14 7,76 .

\section{Biaya Pakan (Rp)}

Biaya pakan didapatkan dari biaya pembelian pakan dikali pakan yang dikonsumsi selama penelitian. Biaya pakan selama penelitian disajikan dalam Tabel 6 .

Tabel 6. Biaya pakan kelinci selama penelitian $\left(\mathrm{R}_{\mathrm{P}}\right)$

\begin{tabular}{lr}
\hline Penambahan tepung biji karet (\%) & Rataan (Rp) \\
\hline Tanpa biji karet & 21.947 \\
3 & 23.067 \\
6 & 21.683 \\
9 & 20.827 \\
\hline
\end{tabular}

Keterangan: Data yang ditampilkan adalah nilai rataan (Rp).

Tabel 6 menunjukkan bahwa biaya pakan yang paling tinggi yaitu pada pemberian wafer dengan penambahan 3\% tepung inti biji karet (Rp. 23.067). Hal ini diduga karena pakan yang dikonsimsi kelinci pada wafer dengan penambahan 3\% tepung inti biji karet lebih banyak dibandingkan dengan perlakuan yang lainnya yakni 4.711,67 gr. Biaya pakan yang rendah terdapat pada perlakuan wafer dengan penambahan $9 \%$ tepung inti biji karet (Rp. 20.827). Hal ini diduga karena pakan yang dikonsumsi lebih sedikit dibandingkan kelinci dengan perlakuan lainnya yakni 4.137,00 gr. 


\section{Kesimpulan}

Penambahan tepung biji karet dalam ransum komplit hingga taraf $9 \%$ belum dapat memperbaiki performa produksi kelinci lokal jantan fase pertumbuhan yang dilihat dari konsumsi pakan, pertambahan bobot badan dan konversi pakan. Biaya pakan yang paling tinggi yaitu pada pemberian wafer dengan penambahan 3\% tepung inti biji karet (Rp. 23.067).

\section{Daftar Pustaka}

Anggraeni dan Afzalani. 1990. Pemanfaatan Tepung Biji Karet (Hevea grasilensis) hingga $15 \%$ dalam Ransum Komersial Ayam Pedaging. Laporan penelitian. Fakultas Peternakan Universitas Jambi.

Diansyah, N. 2016. Penggunaan Ampas Kelapa Fermentasi dalam Ransum Terhadap Performa Ayam Pedaging. Skripsi. Fakultas Pertanian dan Peternakan. UIN Suska Riau. Pekanbaru.

Dinas Perkebunan Provinsi Riau. 2015. Luas Areal Perkebunan Menurut Jenis Tanaman dan Kabupaten/Kota.2015. https://riau.bps.go.id.

Endrayani, S. 2006. Pengaruh Penambahan Tepung Biji Karet Dalam Ransum Terhadap Kecernaan Bahan Kering dan Bahan Organik Domba Lokal Jantan. Skripsi. Fakultas Pertanian Universitas Sebelas Maret Surakarta.

Karima R. 2015. Pengaruh Perendaman dan Perebusan Terhadap Kadar HCN pada Biji Karet. Jurnal Riset Industri Hasil Hutan 7(1): 39-44.

Lubis, A.A.S. 2017. Substitusi Ransum Komersial dengan Tepung Biji Karet (hevea brasilensis) Fermentasi Terhadap Produksi Karkas dan Lemak Abdominal Ayam Pedaging. Skripsi. Fakultas Pertanian dan Peternakan. UIN Suska Riau. Pekanbaru.

Marufah, I. 2016. Kandungan Nutrisi Urea Molases Blok (UMB) dengan Bahan Pengisi Ampas Sagu Sebagai Substitusi Dedak Padi. Skripsi. Fakultas Pertanian dan Peternakan. UIN Suska Riau. Pekanbaru.

Maryani, A., Kardaya. D dan Dihansih. E. 2015. Performa Produksi Kelinci Lokal yang Diberikan Pakan Tambahan Tepung Daun Sirsak. Jurnal Peternakan Nusantara. Fakultas Pertanian Universitas Djuanda Bogor. Bogor. 1(1): 17-24.

Parrakkasi, A. 1995. Ilmu Gizi dan Makanan Ternak Ruminansia. UI-Press. Jakarta.

Patrick, H and Schaible, P.J. 1980. Poultry Feed and Nutrition. $2^{\text {nd }}$ Edition. Avi Pub. Co. Inc. Westport, Connecticut. 
Pratiwi, N.N., 2008. Pengaruh Substitusi Konsentrat dengan Tepung Biji Karet dalam Ransum Terhadap Performan Kelinci New Zealand White Jantan. Skripsi. Fakultas Pertanian Universitas sebelas Maret Surakarta.

Rahmawan, O. Dan Mansyur. 2008. Detoksifikasi HCN dari Bungkil Biji Karet (BBK) Melalui Berbagai Perlakuan Fisik. Seminar Nasional Teknologi Peternaka dan Veteriner. Fakultas Peternakan Universitas Padjajaran. Jatinangor.

Siahaan S.2009. Potensi Pemanfaatan Limbah Biji Karet (Hevea brasiliensis) Sebagai Sumber Energi Alternatif Bioerosin untuk Keperluan Rumah Tangga (Studi Kasus di Desa Nanga Jetak Kecamatan Dedai Kabupaten Sintang Kalimantan Barat). Tesis. Bogor. Institut Pertanian Bogor.

Sitorus, P., S. Soediman, Y.C. Raharjo, I.G. Putu, Santosa, B. Sudaryanto dan A. Nurhadi. 1982. Laporan Budidaya Peternakan Kelinci di Jawa. Pusat Penelitian dan Pengembangan Peternakan, Departemen Pertanian, Bogor.

Steel R. G. D and J. H. Torrie. 1991. Prinsip dan Prosedur Statistika, Edisi ke-2, B Sumantri, penerjemah. Jakarta: Gramedia Pustaka Utama. Terjemahan dari: The Principle and Prosedure of Statistics.

Trisyulianti, E., Suryahadi dan V. N. Rakhma. 2003. Pengaruh Penggunaan Molasses dan Tepung Gaplek Sebagai Bahan Perekat Terhadap Sifat Fisik Wafer Ransum Komplit. Med.Pet. 26: 35-40.

Utari, F.D.,B. W. H. E.Prasetiyono,dan A.Muktiani. 2012. Kualitas Susu Kambing Perah Peranakan Ettawa yang diberi Suplementasi Protein Terproteksi dalam Wafer Pakan Komplit Berbasis Limbah Agroindustri. Anim.Agric. J. 1 (1): 426- 447.

Wiqar, A. 2009. Pengaruh Substitusi Konsentrat dengan Tepung Daun Wartel dalam Ransum Terhadap Performan Kelinci Lokal Jantan. Skripsi. Fakultas Pertanian Universitas Sebelas Maret. Surakarta. 